\title{
Insider power breeds human capitalists
}

Citation for published version (APA):

Muysken, J., \& Zwick, T. (1996). Insider power breeds human capitalists. METEOR, Maastricht University School of Business and Economics. METEOR Research Memorandum No. 030

https://doi.org/10.26481/umamet.1996030

Document status and date:

Published: 01/01/1996

DOI:

10.26481/umamet.1996030

Document Version:

Publisher's PDF, also known as Version of record

\section{Please check the document version of this publication:}

- A submitted manuscript is the version of the article upon submission and before peer-review. There can be important differences between the submitted version and the official published version of record.

People interested in the research are advised to contact the author for the final version of the publication, or visit the DOI to the publisher's website.

- The final author version and the galley proof are versions of the publication after peer review.

- The final published version features the final layout of the paper including the volume, issue and page numbers.

Link to publication

\footnotetext{
General rights rights.

- You may freely distribute the URL identifying the publication in the public portal. please follow below link for the End User Agreement:

www.umlib.nl/taverne-license

Take down policy

If you believe that this document breaches copyright please contact us at:

repository@maastrichtuniversity.nl

providing details and we will investigate your claim.
}

Copyright and moral rights for the publications made accessible in the public portal are retained by the authors and/or other copyright owners and it is a condition of accessing publications that users recognise and abide by the legal requirements associated with these

- Users may download and print one copy of any publication from the public portal for the purpose of private study or research.

- You may not further distribute the material or use it for any profit-making activity or commercial gain

If the publication is distributed under the terms of Article $25 \mathrm{fa}$ of the Dutch Copyright Act, indicated by the "Taverne" license above, 


\title{
Insider Power Breeds Human Capitalists
}

\author{
Joan Muysken and Thomas Zwick*
}

\begin{abstract}
The focus of this paper is on rent distribution under different labour market regimes. When workers determine human capital investment and wages freely, while the firm sets labour demand, the rent created is shared. Investment in human capital is then inefficiently low. When there are unemployed potential entrants threatening to enter and catch some of the rent, however, the insiders have to concede a higher share of the rent to the firm. They might however erect barriers to entry by sinking costs for investment in human capital. It is shown under which circumstances rents are shared between insiders and outsiders by allowing the latter ones to enter the labour market. Finally, it is shown which consequences on rent creation and labour demand the behaviour of the insiders has.
\end{abstract}

\section{Introduction}

This paper shows the consequences of potential entry into the labour market on rent creation and appropriation of the workers. The main question is, if insiders gain market power, when there are no transaction costs for labour turnover, but sunk costs are required for human capital investment. The outsiders and insiders are assumed to be identical. The only differences are that the insiders have a first-mover advantage that gives them the possibility to influence the behaviour of the outsiders by committing themselves. In addition to that it is assumed that insiders are offered the jobs before the outsiders, if the profit offer is the same.

In order to compare the positions of the various parties on the labour market, we choose as a benchmark a perfectly functioning labour market where the entire labour supply is employed and investment is efficient, if the insiders have no market power. The benchmark is used to analyze the consequences of market power of the insiders on rent distribution and rent creation.

The extreme form of insider power can be found in a model where the incumbent workers face no job competition from potential entrants. This scenario is

${ }^{*}$ We want to thank William Baumol, Frank Bunte, Hans Dewachter, Marco Haan, Ralph Olthoff, colloquium participants in Regensburg, Lüneburg and Maastricht and especially Erik de Regt and Thomas Ziesemer for helpful comments. The usual disclaimer of course applies. 
called the monopolistic worker scenario. When there are active outsiders present, they will offer the maximum profit to the firm in order to maximize their chance to enter the labour market. The insiders have to equal that profit offer, if they do not want to be replaced by their rivals. It will be shown that the insiders are able to hinder the entry of the outsiders by sinking costs in human capital formation.

In an alternative scenario, the cooperation scenario, the assumption of the outsiders' behaviour is changed from maximizing the profit of the firm to cooperation with the insiders. Then both groups of workers are employed and the part of the rent attributed to the workers is shared between insiders and entrants.

\section{The structure of the model}

In order to tackle the question, if rent appropriation of insiders may arise due to human capital investment, the contestability theory (see e.g. Baumol (1982) or Baumol, Panzar and Willig (1988)) is applied to the labour market. The results of the labour market are therefore not determined by conjectural variations of the incumbents or bargaining between employers and employees, but by pressures of (potential) entry. As in contestability theory, potential competition serves as a disciplinary device for the wage setting and investment in human capital of the incumbents. One important feature of contestable market theory, hit-andrun entry, is, however, excluded in the labour market context. On the other hand, the application to the labour market has the advantage that there arein contrast to industrial organization - "natural" potential entrants if there is unemployment. In addition, rigid wages are not as problematic an assumption, if we assume wage bargaining where wages are fixed for a certain period. In this case it can be assumed that labour demand is more flexible than wages.

The most obvious application of the idea that potential entry may have an influence on the decisions of incumbents on the labour market is the insider-outsider approach à la Lindbeck and Snower (1988). Here all outsiders are unemployed potential entrants and compete with the incumbents in wage setting and supply of human capital. Rent appropriation is explained in these models by reasons as sinking costs for harassment, labour turnover costs and the effects of labour turnover on effort.

The crucial new assumption in our model is that there are no transaction costs (as assumed in perfectly contestable markets), i.e. that entry and exit is costless. This is assumed in order to see if the introduction of sunk costs for labour market investments leads to a market power (i.e. the possibility to appropriate rents) of the insiders that is comparable with transaction costs. In order to give the outsiders as much "aggressiveness" and the same position as the insiders (as assumed in perfect contestable markets), outsiders offer the firm the highest possible profit in order to maximize their chance to enter the labour market. Moreover, we assume that the human capital endowment and the possibilities to 
create new special human capital are identical for insiders and outsiders. The later assumptions can be motivated by the notion that the outsiders may be recently dismissed and have therefore still no comparative disadvantage with respect to the insiders in the industry they until recently worked in. In addition, they know that their human capital would depreciate over time and therefore they are aggressive in order to reenter as soon as possible. Investments in human capital always entail elements of sunk costs as they cannot be fully used in other employment relations. In order to sharpen the argument, we assume that only special human capital is needed in the labour market in question, while productivity in other firms is not affected by additional specific human capital. ${ }^{1}$ This, however, introduces sunk costs in the model that can lead to market power of the insiders or induce barriers to entry. ${ }^{2}$

Our insider-outsider scenario preserves most of the salient structural assumptions taken by Lindbeck and Snower (1988):

1. Each employee's bonus is negotiated for one period at a time. (The notion of an initiation period for entrants before they are insiders is skipped here.) This bonus is related to the investment in human capital and is in addition to some fixed basic wage.

2. Outsiders are perfect competitors for jobs, i.e. insiders and outsiders are assumed to be equally productive before investment into human capital takes place. Therefore the entrant's bonus is equal to the lowest possible level.

3. Each insider sets his/her bonus individually, taking the strategies of all other agents as given.

4. The insider's bonus is contingent on his investment in human capital. This is in contrast to the incontingency of insider's wages on cooperation and harassment activities in Lindbeck and Snower's model.

5. Employment decisions are made unilaterally by the firm.

6. In the last stage, the firm makes the employment decisions, taking the bonus demand and human capital levels as being given. These parameters are set by the insiders first and the outsiders react to them.

Due to this symmetrical set-up without turnover costs, the insiders are not able to acquire rents, if there would be no opportunity to invest in specific human capital.

\section{$2.1 \quad$ The firm}

The firm maximizes its profits $\pi$. We assume that the production function of the firm is of Cobb-Douglas type. ${ }^{3}$ The revenues of the firm depend on the number of

\footnotetext{
${ }^{1}$ See Becker (1983) pp. $26 \mathrm{ff}$. for the classification in general and special human capital.

${ }^{2}$ Compare e.g. Baumol, Panzar and Willig (1988) pp. $290 \mathrm{ff}$. , Shepherd (1984) and Stiglitz (1987).

${ }^{3}$ The production function with homogeneous labour input and human capital input is similar to the formulation in Lindbeck and Snower (1991), p. 194. The effort part is substituted by
} 
workers $l$ and the homogeneous level of new human capital per worker $c$ gained by the workers. In the next period, the new investment into human capital would be added and therefore productivity increases over time. In order to keep the model as simple as possible, we do not take that into account, however. The firm pays a "basic" wage $w$ and a bonus $b$ dependent on the level of new human capital. This is a partial equilibrium model, where the market wage $w$ and labour productivity $A$ are assumed to be exogeneously given. Therefore the profit function of the firm reads as:

$$
\pi=A l^{\beta} c^{\gamma}-(b c+w) l
$$

with $0<\beta<1$ and $0<\gamma<1$.

Here the price of the good produced is normalized to unity. It can be shown that the revenue function is valid under different elasticities of demand or market structures. $^{4}$ The parameter $c$ denotes specific new human capital per worker and it is assumed that without this specific human capital that is gained in the preceding stage, production is not possible. The firm sets its labour demand and takes the level of specific new human capital and the bonus that has to be paid for it as given. Notice that the firm just accepts workers with the same amount of human capital. Outsiders are therefore hired in addition to insiders, only if they offer the same human capital. There is also, however, the possibility that all insiders are replaced by outsiders, if the human capital differs and outsiders offer a higher profit to the firm.

From the profit function of the firm (1), the demand for labour can be derived by taking the first order condition with respect to $l$ :

$$
l=\left(\frac{\beta A c^{\gamma}}{b c+w}\right)^{\frac{1}{1-\beta}}
$$

Firm's labour demand is therefore negatively dependent on the costs for labour $b$ and $w$, while the impact of investment in human capital $c$ depends on the size of $c$ : for small $c$ it is increasing, for larger $c$ it decreases. This is due to the concavity of the revenue function and the linearity of the cost function with respect to $c$.

\subsection{The workers}

There is a potential labour force of $L$ workers, made up from $l_{-1}$ insiders and $n$ outsiders in the initial period. The homogeneous insiders optimize individually their surplus that is defined as the monetary income. ${ }^{5}$ They can determine

new human capital. In this, it is implicitly assumed that higher specific job skills lead to higher productivity (as higher effort leads to higher productivity).

${ }^{4}$ See appendix.

${ }^{5}$ The same conclusions could also be achieved by introducing a union of insiders, compare Lindbeck and Snower (1990), p. 195. 
the investment in specific human capital (and therefore the resulting level of $c$ ) and the bonus $b$ they obtain. There is however a trade-off between the human capital/bonus combination and the certainty to be able to keep the job. The labour demand of the firm is falling when there is a higher bonus demand if the human capital is kept equal. If labour demand is smaller than the number of insiders in the previous period $l_{-1}$, then every worker faces the same probability to lose his/her job. Insiders are therefore not interested in total labour demand, but in labour demand relative to supply in the previous period. Moreover each insider assumes then that she/he is the marginal worker in the firm's employment decision. ${ }^{6}$

In defining the surplus function of the insiders, two situations can be distinguished. In both cases it is assumed that the insiders can outperform the outsiders. The first possibility is found when $l \geq l_{-1}$. The surplus function for insiders reads as:

$$
s=(b c+w)-(1+r) c^{2}
$$

That is, the insiders earn the wage in the primary labour market $w$ plus the bonus $b$ on special human capital with certainty, while they have to subtract the investment in specific capital. The costs of investment are assumed to be quadratic in the amount of human capital, $c$, therefore the investment in specific human capital shows decreasing returns to scale. As the investment is done in the previous period, the interest costs for investment in specific human capital have to be taken into account, where $r$ is the exogeneous rate of interest (or the individual discount rate).

The second possibility is that $l<l_{-1}$. Then we find: ${ }^{7}$

$$
s=\frac{l}{l_{-1}}(b c+w)+\left(1-\frac{l}{l_{-1}}\right) \bar{s}-(1+r) c^{2}
$$

The wage and bonus mark-up over the outside option is earned with probability $\frac{l}{l_{-1}}$. The exogeneous outside option $\bar{s}$ is earned in the case of unemployment, while the investment costs have to be made with certainty.

The same arguments apply for the outsiders, who have to divide the labour demand of the firm by the number of outsiders in the initial period $n$. If labour demand is larger than the number of insiders in the previous period, the firm will

\footnotetext{
${ }^{6}$ See also Lindbeck and Snower (1988), p. 172. By assuming that the workers are equal and taking the consequences of their decisions into account, we circumvent the problem that individually rational decisions may produce inferior solutions in prisoners-dilemma structures (compare e.g. Vogt (1986)). The main argument in favour of this assumption is the right of the workers to set the bonus themselves and therefore being able to directly influence the labour demand of the firm.

${ }^{7}$ This is the formulation for the objective functions of workers (unions) most widely spread, compare e.g. Layard, Nickell and Jackman (1991), p. 100 and Carrut and Oswald (1987), p. 433.
} 
hire outsiders if they offer the same level of special human capital as the insiders, because the production function does not allow for employment of workers with different levels of human capital. If $l<n$, the analogous surplus function of the outsiders reads as:

$$
s=\frac{l}{n}(b c+w)+\left(1-\frac{l}{n}\right) \bar{s}-(1+r) c^{2}
$$

Otherwise equation (3) also defines the surplus of the outsider.

\section{Different scenarios}

\subsection{The benchmark scenario}

A typical benchmark case would be to introduce a social planner who maximizes the total rent from investment in human capital. The total rent is defined by: $R=\pi+L s$, that is total rent equals the sum of consumer and producer surplus. In the full employment case $l \geq L$, this can be rewritten:

$$
R=A L^{\beta} c^{\gamma}-(1+r) L c^{2}
$$

In the unemployment case $l<L$, the sum of consumer and producer surplus equals:

$$
\widetilde{R}=A l^{\beta} c^{\gamma}+(L-l) \bar{s}-(1+r) L c^{2}+\widetilde{w}(L-l)
$$

with $\widetilde{w} \geq 0,(L-l) \geq 0$ and $\widetilde{w}(L-l)=0$. Here, $\widetilde{w}$ is the shadow price of unemployment. If $\widetilde{R}$ is maximized with respect to $c$ and $l$ simultaneously, we find for labour demand: ${ }^{8}$

$$
\widetilde{l}=\left(\frac{\beta A}{\bar{s}}\right)^{\frac{2-\gamma}{2-2 \beta-\gamma}}\left(\frac{\gamma A}{2(1+r) L}\right)^{\frac{\gamma}{2-2 \beta-\gamma}}
$$

It seems reasonable to assume that the social planner will set the level of the exogeneous outside option such that labour demand is not lower than labour supply. Setting $\widetilde{l}$ equal to $L$, we find from (7) that for the outside option should hold:

$$
\bar{s}<\widehat{s}=\frac{\beta}{L}\left(\frac{\gamma^{\gamma} A^{2} L^{2 \beta-\gamma}}{2^{\gamma}(1+r)^{\gamma}}\right)^{\frac{1}{2-\gamma}}
$$

For analytical clarity, we introduce the parameter $\epsilon$ to indicate the ratio between $\bar{s}$ and the maximum outside option $\hat{s}$ :

$$
\bar{s}=\epsilon \widehat{s}, \epsilon \leq 1
$$

\footnotetext{
${ }^{8}$ Notice that in this scenario, the firm is not on its labour demand function (2).
} 
Efficient investment in human capital is therefore found when total rent with full employment (6) is maximized with respect to $c$ :

$$
c^{\mathrm{r}}=\left(\frac{\gamma A}{2(1+r) L^{1-\beta}}\right)^{\frac{1}{2-\gamma}}
$$

It is interesting to note that these results are consistent with a situation in which the workers choose the optimal profit for the firm in order to maximize their probability to enter the labour market. The optimal profit that can be offered by the potential entrants is calculated by attributing the right to determine all parameters to the firm. The workers are not willing to invest in a job that gives them an expected surplus lower than their outside option, however. Hence the profit function of the firm (1) is maximized under the constraint that the surplus (3) equals the outside option.

It will be assumed that also the social planner attributes the entire rent in excess to $\bar{s}$ to the firm. We do this in order to be able to assess the impact of market power of the workers on the functioning of the labour market in the following scenarios.

Substituting $c^{\mathrm{r}}, L$ and the minimal bonus (i.e. $b$ such that the surplus with labour certainty (3) is equal to $\bar{s}$ ) into the profit function of the firm then gives the benchmark profit level if the entire excess rent is attributed to the firm:

$$
\pi^{\mathrm{r}}=\left(1-\frac{\gamma}{2}-\epsilon \beta\right)\left(\frac{\gamma^{\gamma} L^{2 \beta-\gamma} A^{2}}{2^{\gamma}(1+r)^{\gamma}}\right)^{\frac{1}{2-\gamma}}
$$

The profit of the firm increases with the competition between the workers $(L$ increases) when $2 \beta>\gamma$, and decreases otherwise. Since the latter result seems counterintuitive, we assume $\beta>\frac{1}{2} \gamma{ }^{9}$ Moreover we assume $\beta+\frac{1}{2} \gamma<1$, since the profit of the firm should always be positive. ${ }^{10}$ The profit of the firm decreases when $\bar{s}$ and $(1+r)$ increase, while it increases with $A$.

\subsection{Monopolistic insider workers scenario}

In this scenario it is assumed that the $n$ outsiders are passive and do not try to enter the market. The $l_{-1}$ monopolistic insider workers have therefore maximal market power. They maximize their surplus by setting bonus demand and the level of special human capital, taking into consideration that the firm determines the amount of labour demanded.

Since the surplus with job uncertainty (4) is always smaller than the surplus with certainty (3), the optimal new human capital - bonus - ratio will be chosen

\footnotetext{
${ }^{9}$ The counter-intuitive result can be explained by a low increase of productivity that is connected with an increase in the labour force if $\beta$ is small, while costs increase linearly with $L$.

${ }^{10}$ This is a sufficient condition which holds exacly, when $\widehat{s}=\bar{s}$.
} 
such that $l=l_{-1} \cdot{ }^{11}$ If the surplus of the insiders (3) is maximized with respect to $c$, and $b$ is set optimally, i.e. such that the labour demand of the firm (2) equals $l_{-1}$, we obtain:

$$
c^{\mathrm{mon}}=\left(\frac{\beta \gamma A}{2(1+r) l_{-1}^{1-\beta}}\right)^{\frac{1}{2-\gamma}}
$$

The investment of the monopolistic workers increases with its efficiency $A$ and decreases with the costs $(1+r)$. When comparing the investment of the monopolistic workers to that in the reference scenario, we find investment to be inefficiently high, i.e. $c^{\text {mon }}>c^{\mathrm{r}}$, when the number of insiders in the last period is smaller than a share $\beta^{\frac{1}{1-\beta}}$ of the entire labour force. ${ }^{12}$ This is due to the fact that the investment of workers increases when the number of competitors $\left(l_{-1}\right)$ decreases, because a lower rent-share has to be transferred to the firm in order to obtain a lower labour demand.

With respect to bonus demand, we find:

$$
b^{\mathrm{mon}}=\frac{A \beta}{l_{-1}^{1-\beta}\left(c^{\mathrm{mon}}\right)^{1-\gamma}}-\frac{w}{c^{\mathrm{mon}}}
$$

In order to make sure that they will be employed, the insiders set a lower bonus demand, if the exogeneous basis wage $w$ is higher. The surplus the monopolistic workers enjoy is calculated by substituting (11) and (12) into (3):

$$
s^{\text {mon }}=\left(\frac{A^{2} \beta^{2} \gamma^{\gamma} l_{-1}^{2 \beta-\gamma}}{2^{\gamma}(1+r)^{\gamma}}\right)^{\frac{1}{2-\gamma}} \frac{(1-\gamma)}{l_{-1}}
$$

In line with our reasoning, it should clearly hold that $s^{\text {mon }}>\bar{s}$. Since $\hat{s}$ is the largest admissible value of $\bar{s}$, see $(8)$, we require that the number of outsiders is so large that $s^{\text {mon }}>\widehat{s}$ holds. ${ }^{13}$

Substituting (11) and (12) into the profit function of the firm (1), we get:

$$
\pi^{\text {mon }}=\left(\frac{\beta^{\gamma} \gamma^{\gamma} A^{2} l_{-1}^{2 \beta-\gamma}}{2^{\gamma}(1+r)^{\gamma}}\right)^{\frac{1}{2-\gamma}}(1-\beta)
$$

Notice that the signs of the comparative statics with respect to the parameters $A$ and $(1+r)$ are the same as in the reference scenario (compare (10)) — this is due to rent sharing. We also find, as in the case of the reference scenario, that in contrast

\footnotetext{
${ }^{11}$ This statement is proven in the appendix.

${ }^{12}$ This corresponds to $] 0,0.368[$ for $\beta=] 0,1[$.

${ }^{13}$ This implies

$$
\frac{l_{-1}}{L}<\left[(1-\gamma)^{2-\gamma} \beta^{\gamma}\right]^{\frac{1}{2(1-\beta)}}
$$

The right-hand side simplifies to $\beta^{\frac{1}{1-\beta}}$ if $\gamma=1-\beta$. Note that this implies $c^{\text {mon }}>c^{\mathrm{r}}$.
} 
to the surplus of the monopolistic workers, the profit of the firm increases with the competition between the workers ( $l_{-1}$ increases) since we assume $2 \beta>\gamma$.

Whether the profit the workers in the reference scenario offer is smaller or larger than that offered by the monopolistic workers depends on the size of two countervailing effects. On the one hand, the profit of the firm in the reference scenario is higher, because there is no inefficient bias in investment due to rent sharing - the entire rent in addition to the outside option is attributed to the firm in the benchmark case. On the other hand, the motivation to invest is for the monopolistic insiders higher, because there are fewer rivals. Taking into account, however, that $\epsilon$ has to be so small that the surplus of the workers $s^{\text {mon }}$ is larger than the outside option $\bar{s}$, it can be shown that this implies that the profit in the reference scenario is larger than in the monopolistic worker scenario. This is intuitive, because the rent generated is maximized in the reference scenario. If in the cooperative scenario with an inefficient investment the profit of the firm would be larger than $\pi^{\mathrm{r}}$, this can only be the case, if $s^{\text {mon }}<\bar{s}$. Therefore, $\pi^{\text {mon }}$ is always smaller than $\pi^{\mathrm{r}}$.

\subsection{The insider-outsider scenario}

In the insider-outsider scenario, we show under which circumstances the insiders are able to erect barriers to entry by investing in human capital. The consequences of barriers to entry for the rent-distribution and rent creation are also highlighted. Here, the incumbents maximize their surplus under the constraint that the outsiders can't outperform them (limit pricing). The time structure of the game is:

\begin{tabular}{|c|c|}
\hline stage & action \\
\hline 1 & insiders invest in human capital and set their bonus demand \\
\hline 2 & outsiders invest in human capital and set their bonus demand, or both not \\
\hline 3 & the firm decides how many people and which ones to employ \\
\hline
\end{tabular}

The insiders invest in human capital in order to signal that in the next period they will be able to match the potential profit offer of the outsiders. The question then is, whether the insiders can credibly threaten that they are able to outperform the outsiders. If so, the outsiders will not invest. To investigate this, we will first define the threat of the outsiders. Then the behaviour of the insiders will be analyzed.

\subsubsection{The problem of the outsiders}

We found in section 3.1 that the benchmark scenario is consistent with a situation in which the workers choose the optimal profit for the firm in order to maximize their probability to enter the labour market. Therefore the case of the outsiders is essentially the reference scenario where the number of workers is not the pool 
of workers, $L$, but the number of outsiders $n .{ }^{14}$ From equation (10), we derive the profit offer of the outsiders, $\pi^{\circ}$ :

$$
\pi^{o}=\left(1-\frac{\gamma}{2}-\epsilon \beta\left(\frac{n}{L}\right)^{\frac{2-2 \beta}{2-\gamma}}\right)\left(\frac{\gamma^{\gamma} n^{2 \beta-\gamma} A^{2}}{2^{\gamma}(1+r)^{\gamma}}\right)^{\frac{1}{2-\gamma}}
$$

The term after $\epsilon$ in this equation is introduced to compensate for the difference between the highest possible outside option in the benchmark scenario, $\widehat{s}$, and its analogue for the outsiders. Notice that $\pi^{\mathrm{o}}<\pi^{\mathrm{r}}$, compare (15) with (14).

As the profit of the firm increases with the number of outsiders, the threat of the outsiders to replace the insiders increases also with their number. If the insiders had no market power, they would have to copy the behaviour of the outsiders in order to be able to keep their jobs. Then the bench-mark scenario would hold, the entire labour force $L$ be employed, the rent maximized and completely given to the firm.

\subsubsection{The problem of the insiders}

The insiders maximize their surplus under the constraint that the demand for labour is larger or equal than $l_{-1}^{15}$ and that $\pi \geq \pi^{\circ}$, i.e. that the insiders will be preferred to the outsiders. With their investment in the first period the incumbents have to show that they are able and willing to match the profit offer of the outsiders.

It is a-priori unclear if the profit offered by the monopolistic insiders is higher or lower than the profit offered by the outsiders. ${ }^{16}$ If $\pi^{\text {mon }}>\pi^{0}$, the insiders are able to keep the outsiders from their jobs without changing their monopolistic behaviour, i.e. the insiders' surplus is $s^{\text {mon }}$. This case is more probable, when $\frac{l_{-1}}{n}$ is large, or if there are only relatively few outsiders. As it is usually assumed in insider-outsider models that the number of outsiders is large, we want to rule out the case where $\pi^{\text {mon }}>\pi^{\circ}$.

If $\pi^{\text {mon }}<\pi^{\circ}$, however, the insiders have to set $b$ and $c$ such that $\pi=\pi^{\circ}$ and $l=l_{-1}$ are valid simultaneously, if they want to keep the potential entrants outside. It can be shown that this strategy may give a surplus for the insiders that is higher than $\bar{s}$. This is formally done by solving labour demand of the firm (2) which is set equal to the number of outsiders, $l_{-1}$, for $b$. This function is

\footnotetext{
${ }^{14}$ It can easily be shown that when the optimal amount of human capital is invested, profits are increasing in the number of outsiders.

${ }^{15}$ Here, once again the argument applies that (4) is always larger than (3), see appendix.

${ }^{16}$ The condition for $\pi^{\text {mon }}>\pi^{\circ}$ is:

$$
\left(\left(1+\frac{l_{-1}}{n}\right)^{2 \beta+\gamma}\left(\frac{l_{-1}}{n}\right)^{2-2 \beta}\right)^{\frac{1}{2-\gamma}}>\frac{2 \beta-\gamma}{2 \varepsilon \beta^{\frac{2}{2-\gamma}}}
$$
}


then substituted in the profit function (1) which is set equal to the profit level the outsiders offer, $\pi^{\circ}$, evaluated at $l_{-1}$ and solved for $c$ :

$$
c^{\mathrm{i}}=\left(\frac{\pi^{o}}{(1-\beta) A l_{-1}^{\beta}}\right)^{\frac{1}{\gamma}}
$$

It is unclear whether the investment of the insiders is larger or smaller than efficient investment $c^{\mathrm{r}}$, see equation (9). The investment of the insiders is inefficiently high, if there are many outsiders and if the outside option is low. The reason is that with lower outside option the bench-mark profit the insiders have to offer is larger and the investment of the insiders increases with the benchmark profit. If the number of rivals increases, the incentive to invest decreases, due to the sunk costs effect. Consequently, investment of the insiders is inefficiently low if the outside option is high and if there are not too many outsiders.

The values obtained for $b$ and $c$, when substituted into the surplus function of the incumbent (3) give finally:

$$
s^{\mathrm{i}}=\frac{\beta \pi^{o}}{(1-\beta) l_{-1}}-(1+r)\left(\frac{\pi^{o}}{(1-\beta) A l_{-1}^{\beta}}\right)^{\frac{2}{\gamma}}
$$

The surplus of the insiders increases when $\frac{l_{-1}}{n}$ is low. This is due to the fact that a small number of insiders have to offer the same profit as a larger number of outsiders. If the number of insiders increases, however, the surplus decreases, which is due to the right of the firm to set employment. This requires a lower bonus demand when the number of insiders increases. It is obvious that the surplus the insiders earn may be larger than the outside option $\bar{s}$. However it is always the case that the surplus of the insiders with outsiders present is smaller than $s^{\text {mon }}$, if not $\pi^{\text {mon }}>\pi^{\circ}$ which we ruled out above. Thus the mere presence of outsiders decreases the market power of the incumbents and forces them to grant a larger part of the rent to the firm and adapt their investment behaviour in order to be able to stay employed. Therefore it is possible that the surplus of the insiders is smaller than their outside option, if they want to prevent outsiders from entry. In this case, barrier to entry is no viable option for the insiders.

It may therefore be optimal for the insiders to cooperate with the outsiders and allow for entry. We discuss this below.

\subsubsection{The cooperative scenario}

In this scenario, we show that it may be optimal for the insiders to offer cooperation to the outsiders, maximizing the joint surplus of both groups of workers and offering therefore part of the rent to the entrants. It is always a dominant strategy for the outsiders to cooperate, if the insiders cooperate, because this grants them - in contrast to the outsider scenario - part of the rent. 
The result is then an investment of the insiders that is calculated by the same method as in the monopolistic worker scenario, but taking into account that the outsiders will be employed also. The outsiders imitate it in the second stage. The investment that maximizes the surplus of the entire work-force is then:

$$
c^{c}=\left(\frac{\beta \gamma A}{2(1+r) L^{1-\beta}}\right)^{\frac{1}{2-\gamma}}
$$

This is a smaller investment than in the monopolistic insider workers scenario (compare (11)), because the workers calculate with a demand for labour of $L$ instead of $l_{-1}$ and behave like monopolists. The investment is also smaller than efficient investment $c^{\mathrm{r}}$. This is due to the fact that the workers cannot claim all the rent from investment. If the workers kept the entire rent created, labour demand would be zero. Therefore the right to set labour demand guarantees the firm a share of the rent, also in the case where the workers cooperate.

The bonus demand, the surplus of the insiders and outsiders and the surplus of the workers are calculated analogously to the monopolistic insider worker scenario in section 3.2:

$$
s^{c}=\left(\frac{A^{2} \beta^{2} \gamma^{\gamma}}{2^{\gamma} L^{2-2 \beta}(1+r)^{\gamma}}\right)^{\frac{1}{2-\gamma}}(1-\gamma)
$$

The surplus of the workers is smaller than that the monopolistic workers enjoy (compare (13)). It is however ambiguous, whether $s^{\mathrm{c}}$ is smaller or larger than $s^{\mathrm{i}}$. The probability that $s^{\mathrm{i}}>s^{\mathrm{c}}$ is large, when the number of unemployed outsiders is large. The surplus the workers enjoy in the cooperative scenario may be even lower than the outside option, because $s^{\mathrm{c}}=(1-\gamma) \beta^{\frac{2}{2-\gamma}} \widehat{s}$, hence $s^{\mathrm{c}}<\widehat{s}$. This is due to the fact, that in the benchmark scenario efficient bargaining between workers and the firm takes place. In this scenario the firm is not at its labour demand curve (2) and the entire rent is attributed to it. Therefore the highest outside option that is admissible with full employment, $\hat{s}$, is higher than in the cooperative scenario. In the cooperative scenario, which is a right-to-manage case, the firm is always on its labour demand curve and the surplus enjoyed by the workers decreases with the number of rivals for the jobs. In addition to that investment is not efficient due to rent sharing which reduces the rent to be distributed.

The associated profit level of the firm is in this scenario:

$$
\pi^{\mathrm{c}}=\left(\frac{\beta^{\gamma} \gamma^{\gamma} A^{2} L^{2 \beta-\gamma}}{2^{\gamma}(1+r)^{\gamma}}\right)^{\frac{1}{2-\gamma}}(1-\beta)
$$

It is unclear, whether the profit the firm earns in the cooperative scenario is higher or lower than that in the reference scenario. Taking into account however-like in the monopolistic workers scenario - that $\epsilon$ has to be so small that the surplus 
of the workers $s^{\mathrm{c}}$ is larger than the outside option $\bar{s}$, it can be shown that this implies that the profit in the reference scenario is larger than in the cooperative scenario. Therefore we can exclude $\pi^{\mathrm{c}}>\pi^{\mathrm{r}}$.

\section{Conclusions}

In this model it is shown that investment in human capital may lead to market power for the insiders and is therefore comparable with insider harassment and cooperation activities (Lindbeck and Snower (1988)), turnover rate used by firms as incentive device (Lindbeck and Snower (1989)) and transaction costs (hiring, training and firing costs, see Lindbeck and Snower (1986)). Therefore the sinking of investments for productivity enhancing human capital may be an additional reason for insider rent appropriation and involuntary unemployment.

Potential entry decreases the market power of the workers, however, and leads to a higher share of the firm of rents generated by investment in human capital. This is in line with the notion of Shepherd (1984), Stiglitz (1987) and Baumol et al (1988) that sinking costs may create market power of the insiders and barriers to entry. This result is, however, only achieved if the outside option of the insiders is not too high and if there is a large number of outsiders.

In the benchmark scenario the efficient investment is derived. A social planner maximizes the rent generated by the investment in human capital under the constraint that the entire labour force is employed. The constraint implies a maximal level of the outside option that can be set by the social planner. In this scenario, the entire rent in addition to the outside option is attributed to the firm in order to see the consequences of market power of the workers.

In the monopolistic workers scenario, it is in the interest of the workers to share rents created by the investment in human capital in order to be sure to be employed also in the next period. The surplus enjoyed by the workers and the profit of the firm both increase with the efficiency of the investment and decrease with its costs. Investment may be higher or lower than efficient. On the one hand, the workers have to share rents, therefore the investments in human capital are biased downwards. On the other hand, there are fewer rivals than in the efficient labour market benchmark (when the outsiders maximize the profit of the firm and the insiders have no market power). Therefore the motivation to invest is higher. The size of both countervailing effects therefore decides the efficiency of the investment of the monopolistic insiders. We assumed that the surplus of the monopolistic workers is always larger than the highest possible outside option, which requires a large enough number of outsiders.

In the insider-outsider scenario, the insiders choose for an investment-bonus combination such that they will keep their jobs for sure and are able to match the offer of their rivals. ${ }^{17}$ The outsiders offer the highest possible profit to the firm in

\footnotetext{
${ }^{17}$ This result is also achieved in comparable insider-outsider settings, compare e.g. Gottfries
} 
order to maximize their chances to enter the labour market, presuming that their human capital will depreciate in the future. In this set-up, the entire labour force will be employed if all workers imitate the efficient bonus-human capital decision of the outsiders. This is the decisive factor that reduces the bargaining power of the insiders. If it is not sustainable to keep the outsiders off, the insiders have the option to let them in by imitating them and grant all the rent to the firm. In this case, investment in human capital is efficient, while the entire labour force is employed.

The insiders are only able to appropriate a part of the rent created by the investment into human capital under very special circumstances, although they have a first mover advantage in committing themselves. The reason for this finding is that sinking costs is also possible for the outsiders (insiders face in this respect no better opportunities) and that the investment in human capital increases rather than decreases rents from the employment of outsiders (as in Lindbeck and Snower). Assuming that the number of outsiders is so large and the outside option is so low that the profit offered by the monopolistic insiders is lower than that offered by the outsider, we find that the presence of outsiders decreases the market power of the insiders. However, there are parameter constellations to be found with a sustainable equilibrium without entry and a surplus of the insiders higher than the outside option where the insiders offer the same profit as the outsiders and labour demand is equal to the number of insiders. This means that the insiders are able even under these circumstances to keep a part of the market power by sinking costs for human capital investment. This market power may be used to erect barriers to entry and enjoy still a higher surplus than the outside option.

However, this is not automatically the case and the surplus of the insiders may be smaller than the outside option. The insiders have to compare the surplus earned with barriers to entry with the surplus enjoyed with letting the outsiders in, i.e. the cooperation scenario. We assume here that the outsiders do not automatically offer the maximal profit which gives them only their outside option (as Lindbeck and Snower assume or as it is assumed in perfect contestability models), but cooperate, if the insiders offer them this opportunity, because that grants them always part of the rent a surplus higher than the outside option. In this case the insiders invest in human capital such that all workers are employed and signal therefore that they are willing to let all outsiders in. The outsiders imitate the investment and bonus demand of the insiders that maximizes the rent for all workers. In the cooperative scenario, the employment is the entire labour force and investment in human capital is lower than in all other scenarios. All workers are able to acquire part of the rent that decreases with the number of competitors, while the firm enjoys a profit that is smaller than in the insideroutsider scenario and the reference scenario.

and Horn (1987) or Carruth and Oswald (1987). 


\section{Appendix}

\subsection{Different demand elasticities and the revenue function}

In this appendix it is shown that different demand elasticities or market power of the firm may be incorporated in the revenue function of the firm in equation (1). If we assume that demand $d$ is defined as:

$$
d=B p^{-\eta}
$$

with $1<\eta<\infty$. The elasticity of firm's demand is lower when the consumers are less elastic for the product and when there is less competition on the market for the product. In order to obtain increasing revenues from production, it is necessary to assume an elastic demand function $(\eta>1)$.

Then revenue $R=p y$ can be rewritten as:

$$
R=B^{\frac{1}{\eta}} y^{1-\frac{1}{\eta}}:=C y^{\kappa}
$$

with $0<\kappa<1$.

This can be rewritten if we use the definition of $y=E l^{\alpha} c^{\delta}$ from equation (1):

$$
R=C E^{\kappa} l^{\kappa \alpha} c^{\kappa \delta}:=A l^{\beta} c^{\gamma}
$$

\subsection{Proof that (4) is always smaller than (3)}

If we maximize (4) with respect to $b$ and $c$ under the constraint that the firm is on its demand for labour function (2), we obtain:

$$
\begin{gathered}
c^{\prime}=\left(\frac{\beta^{1+\beta} A}{\bar{s}^{\beta}}\right)^{\frac{1}{2-2 \beta-\gamma}}\left(\frac{\gamma}{2(1+r) l_{-1}}\right)^{\frac{1-\beta}{2-2 \beta-\gamma}} \\
b^{\prime}=\frac{\bar{s}}{c^{\prime} \beta}-\frac{w}{c^{\prime}}
\end{gathered}
$$

Then (4) can be rewritten to:

$$
s^{\prime}=\frac{l \bar{s}}{\beta}(1-\beta)-(1+r) c^{2} l_{-1}
$$

Notice that $\frac{\partial s}{\partial \bar{s}}>0$. The maximal $\bar{s}$ into $s^{\prime}$ that is consistent with $l<l_{-1}$, is obtained by substituting $b^{\prime}$ and $c^{\prime}$ into (2):

$$
\bar{s}^{\prime}<\frac{\beta^{2} A}{l_{-1}^{1-\beta}}\left(\frac{\beta^{4-\gamma} A^{2} \gamma^{\gamma}}{2^{\gamma}(1+r) \gamma l_{-1}^{2(1-\beta)}}\right)^{\frac{1}{2-\gamma}}
$$


Notice that $\bar{s}^{\prime}$ is only smaller than $\widehat{s}$ (compare (8)), if $\frac{l_{-1}}{L}>\beta^{\frac{1}{1-\beta}}$ which would imply $c^{\text {mon }}<c^{\mathrm{r}}$. The entire scenario is however not viable, if $1-\beta<\gamma$. This can be seen from the condition on $\frac{l_{-1}}{L}$ implied by $s^{\text {mon }}>\bar{s}$ (compare footnote 13). If $1-\beta<\gamma$, footnote 13 is not fulfilled for $\beta^{\frac{1}{1-\beta}}$. If we have $1-\beta>\gamma$, however, we have to show that $s^{\text {mon }}>s^{\prime}$.

If we substitute the maximal consistent outside option $\bar{s}^{\prime}$ into $s^{\prime}$, we obtain:

$$
s^{\prime}=\left(\frac{A^{2} \beta^{2} \gamma^{\gamma} l_{-1}^{2 \beta-\gamma}}{2^{\gamma}(1+r)^{\gamma}}\right)^{\frac{1}{2-\gamma}} \frac{\left(1-\beta-\frac{\gamma}{2}\right)}{l_{-1}}
$$

It is clear that $s^{\prime}$ is smaller than $s^{\text {mon }}$ (compare (13)), because we have assumed $2 \beta<\gamma$ in order to obtain a rising profit with a growing number of rivals (see section 3.1).

\section{References}

[1] Baumol, W. (1982). Contestable markets: An up-rising in the theory of industrial structure. American Economic Review, 72: 1-15.

[2] Baumol, W., Panzar, J. and Willig, R. (1988). Contestable markets and the theory of industry structure. Harcourt Brace Jovanovich, San Diego.

[3] Becker, G. (1983). Human capital. 2nd edition. The University of Chicago Press, Chicago.

[4] Carruth, A. and Oswald, A. (1987). On union preferences and labour market models: Insiders and outsiders. The Economic Journal, 97: 431 - 445.

[5] Gottfries, N. and Horn, H. (1987). Wage formation and the persistence of unemployment. The Economic Journal, 97: 877-884.

[6] Layard, R., Nickell, S. and Jackman, R. (1991). Unemployment - Macroeconomic performance and the labour market. Oxford University Press, Oxford.

[7] Lindbeck, A. and Snower, D. (1986). Wage setting, unemployment, and insider-outsider relations. American Economic Review, 76: 235-239.

[8] Lindbeck, A. and Snower, D. (1988). Cooperation, harassment, and involuntary unemployment: An insider-outsider approach. American Economic Review, 78: 167-188.

[9] Lindbeck, A. and Snower, D. (1989). Job security, work incentives and unemployment. In Honkapohja, S., editor, Information and incentives in organizations. Basil Blackwell, Oxford. 
[10] Lindbeck, A. and Snower, D. (1990). Demand- and supply-side policies and unemployment: Policy implications of the insider-outsider approach. Scandinavian Journal of Economics, 92(2): 279-305.

[11] Lindbeck, A. and Snower, D. (1991). Interactions between the efficiency wage and insider-outsider theories. Economics-Letters, 37: 193-196.

[12] Shepherd, W. (1984). 'Contestability' vs. competition. American Economic Review, 74: 572-587.

[13] Stiglitz, J. (1987). Technological change, sunk costs, and competition. Brookings Papers on Economic Activity, 3: 883-937.

[14] Vogt, W. (1986). Theorie der kapitalistischen und einer laboristischen Ökonomie. Campus, Frankfurt/M. 